\title{
Die „Macht" der Bauern? Agrargesellschaft im Wandel
}

Abstract: Die zentrale Fragestellung dieses Beitrags lautet: Wie kam es zur Herausbildung eines deutlichen Standesbewusstseins der niederösterreichischen Bauern im I9. Jahrhundert und was bedeutete diese Veränderung für die Machtverhältnisse im Land? Vor I 848 unterstand die bäuerliche Bevölkerung durchwegs feudalen Grundherren. Nur eine unbedeutende Selbstverwaltung auf dörflicher Ebene stand ihr zu. Nach dem Ende des Feudalismus durch die Grundentlastung (I 848) wurden autonome Gemeinden gebildet, in denen nun auch die größeren Bauern mitbestimmen konnten. Der ab i 86r/67 herrschende Liberalismus erschütterte die traditionellen Verhältnisse. Verschuldung und Preisverfall führten ab i 880 zu krisenhaften Erscheinungen. Die Artikulation der bäuerlichen Probleme durch einen Weinbauern (Steininger) und sozialpolitisch interessierte Fachleute und Politiker ließ durch die Gründung von Fachvereinen und Genossenschaften ein immer dichteres agrarisches Netzwerk entstehen. Letztlich mündeten diese Bemühungen in der Gründung einer erfolgreichen politischen Organisation, des Niederösterreichischen Bauernbundes, die als Ausdruck der Entstehung eines auch politisch umsetzbaren Standesbewusstseins gelten kann.

The Power of the Peasants? The Transformation of Agrarian Society. This chapter examines the development of a clear estate consciousness among the Lower Austrian peasantry in the nineteenth century and considers its implications for power relations in the land. Prior to I 848 , the peasant population were ruled by feudal landowners, and were entitled to an insignificant degree of self-governance only on the village level. When the landholding reform (Grundentlastung) put an end to feudalism in I848, autonomous communes were formed in which the upper peasantry now had some say. The liberalism that prevailed from г 86I/67 onwards shattered the traditional societal foundations, and crisis set in with debt and a steep decline in prices from I 880 onwards. The articulation of peasants' problems by a vintner (Steininger) and experts and politicians with an interest in social welfare saw the emergence of an increasingly dense agrarian network via specialist associations and trade unions. Ultimately, these efforts culminated in the foundation of a successful political organisation, the Lower Austrian Farmers' Association, which may be considered a manifestation of athe emergence of an estate consciousness realisable on the political level.

Keywords: rural communities, social estate of peasantry, estate consciousness, emancipation of peasants, peasant organizations, agricultural cooperatives 